\title{
7. ISOTOPE GEOCHEMISTRY OF SYNTECTONIC CARBONATE CEMENTS AND VEINS FROM THE OREGON MARGIN: IMPLICATIONS FOR THE HYDROGEOLOGIC EVOLUTION OF THE ACCRETIONARY WEDGE ${ }^{1}$
}

\author{
James C. Sample ${ }^{2}$ and Achim Kopf ${ }^{3}$
}

\begin{abstract}
Isotopic compositions of carbonate cements are used to infer the compositions of historical pore fluids of Sites 891 and 892 (Oregon transect) of Ocean Drilling Program Leg 146 (Cascadia Margin). Site 891 was drilled through the frontal thrust region, and Site 892 penetrated an out-of-sequence thrust farther upslope. Carbonate content in the non-concretionary samples analyzed from Site 891 ranges from $0 \%$ to 14\%. Calcite and magnesian calcite are the dominant diagenetic carbonate phases, and dolomite is present in many samples. Generally carbonate contents and compositions do not correlate well with related dissolved constituents (alkalinity, $\mathrm{Mg}^{2+}, \mathrm{Ca}^{2+}$ ) in modern pore-water chemistry. $\delta^{13} \mathrm{C}_{\mathrm{PDB}}$ values of samples from this site range from $-4.4 \%$ to $-0.8 \%$; oxygen isotope values from the same samples range from $\delta^{18} \mathrm{O}_{\mathrm{PDB}}=-16.5 \%$ to $-6.2 \%$, and are substantially out of equilibrium with the oxygen isotopic composition of the pore waters. Both stable isotopes show a relatively smooth variation with depth. Strontium isotopes of six samples range from ${ }^{87} \mathrm{Sr} /{ }^{86} \mathrm{Sr}=0.70990$ to 0.71155 and are substantially more radiogenic than modern seawater $(\approx 0.7092)$.

Carbonate content in the non-concretionary samples analyzed from Site 892 are higher and range from $0 \%$ to $25 \%$. Calcite and magnesian calcite are the dominant diagenetic carbonate, but dolomite is common in the upper part of the section. The amount of carbonate correlates better with pore-water alkalinity profiles, and dolomite tends to occur where $\mathrm{Mg} / \mathrm{Ca}$ ratios in pore water are highest, but there is not a strict correlation between carbonate occurrence and pore water profiles. Twenty-seven samples have a large range of carbon isotope values $\left(\delta^{13} \mathrm{C}_{\mathrm{PDB}}=-30 \%\right.$ to $+26 \%$ ); oxygen isotope values from the same samples range from $\delta^{18} \mathrm{O}_{\mathrm{PDB}}=-14 \%$ to $+11 \%$. Most of the oxygen isotopes are substantially out of equilibrium with oxygen isotope composition of the pore waters; on the other hand, carbon isotopes measured on dissolved total $\mathrm{CO}_{2}$ are high and may explain some of the high $\delta^{13} \mathrm{C}$ values of the diagenetic carbonates. Both stable isotopes show large fluctuations in their profiles with depth. Strontium isotopes of eight samples range from ${ }^{87} \mathrm{Sr} /{ }^{86} \mathrm{Sr}=0.70576$ and 0.70885 and are substantially less radiogenic than modern seawater; one sample has a ratio of 0.71140 . Most of these values are not in the range of the pore water strontium isotope composition.

The oxygen, carbon, and strontium isotope characteristics of Site 891 diagenetic carbonates suggest that deep fluids have migrated from the décollement and other fluid conduits up through most of the stratigraphic section. Isotope-depth patterns of Site 892 diagenetic cements are more complex, reflecting greater deformation, a longer history of fluid flow, and a greater influence of shallow fluid reservoirs involving organic-rich sediments.
\end{abstract}

\section{INTRODUCTION AND GEOLOGIC BACKGROUND}

Ocean drilling at the Cascadia Margin during Ocean Drilling Program (ODP) Leg 146 focused on hydrogeologic processes related to convergent margin tectonics and the origin of gas hydrates. This paper summarizes data from the two sites in the Oregon margin (Fig. 1) that were drilled to provide an opportunity to examine differences between the initial stages of tectonic dewatering at the frontal thrust (Site 891) and a more prolonged history of fluid flow at the out-ofsequence thrust (Site 892). This paper presents chemical and isotope data from diagenetic carbonate cements, which serve as a record of the fluid evolution at Sites 891 and 892 .

At the latitudes of Sites 891 and 892, the Juan de Fuca plate converges beneath the North American plate at a rate of $39 \mathrm{~mm} / \mathrm{yr}$ in a northeasterly direction (DeMets et al., 1990). Turbidites composing Astoria Fan sediments derived mainly from the Columbia River are incorporated into the accretionary wedge, while part of the turbidites and the hemipelagic section are subducted beneath the wedge (MacKay et al., 1992). The age of oceanic crust is about $9 \mathrm{Ma}$ at the deformation front. The structure of the portion of the Oregon margin

Carson, B., Westbrook, G.K., Musgrave, R.J., and Suess, E. (Eds.), 1995. Proc. ODP, Sci. Results, 146 (Pt. 1): College Station, TX (Ocean Drilling Program).

${ }^{2}$ Department of Geological Sciences, California State University, Long Beach, CA 90840-3902, U.S.A.

${ }^{3}$ Geologisches Institut, Unversitaet Giessen, Senckenbergstrasse, D63000 Giessen, Federal Republic of Germany. drilled during Leg 146 is characterized by north-striking, seawardverging thrust faults and folds; some west-striking strike-slip faults may be tear faults accommodating differences in structure along the strike of the thrusts (MacKay et al., 1992). The frontal ridge (penetrated by Site 891 ) is underlain by a ramp anticline above the frontal thrust. The second ridge (penetrated by Site 892) is underlain by a prominent reflector interpreted to be an out-of-sequence thrust fault (Westbrook, Carson, Musgrave, et al., 1994). Both sites are near areas investigated previously with Alvin dives (Kulm et al., 1986; Sample and Reid, in press), which provided evidence for fluid seepage at the sea floor in the form of chemosynthetic benthic communities, elevated methane concentrations, and inorganic carbonate crusts (Linke et al., 1994).

\section{Site 891}

Three holes were drilled at Site 891 , with a total penetration of 472 meters below sea floor (mbsf), at 2663 meters below sea level $(\mathrm{mbsl})$ in a small submarine canyon located about $5 \mathrm{~km}$ south of a larger canyon investigated previously with Alvin. The Alvin study found that fluid seepage is occurring primarily along a backthrust located near the top of the frontal ridge, with secondary seepage occurring along stratigraphic conduits in the main submarine canyon (Moore et al., 1990). The backthrust appears to be capturing fluids flowing up the décollement towards the front of the wedge. Some evidence for seepage along the frontal thrust fault trace was observed in the form of bacterial mats, clam shells, and carbonate crusts at a depth 
Figure 1. Location map of Sites 891 and 892. Site 891 is on seaward flank of ramp anticline underlying first ridge, east of frontal thrust and proto-thrust zone. Site 892 is at top of second ridge, east of bioherm and out-of-sequence thrust penetrated at site. Western limit of bottom-simulating reflector (BSR) as appears in seismic reflection profiles is shown by thick, dashed line. Bathymetric contour interval is $100 \mathrm{~m}$.

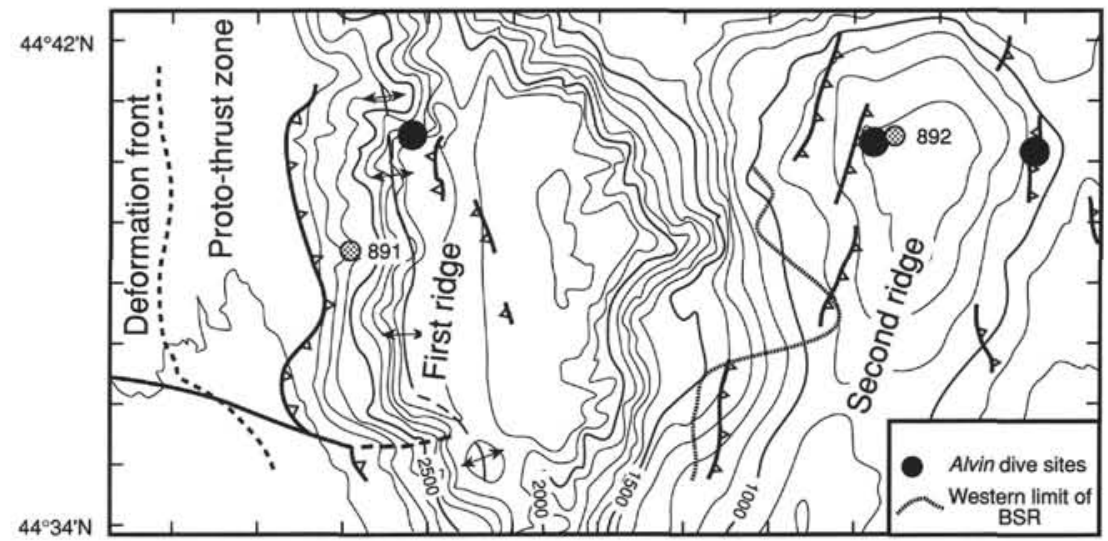

of $2770 \mathrm{mbsl}$. Diagenetic carbonates associated with fluid seeps in the large submarine canyon farther north have geochemical signatures that suggest relatively deep fluid sources. These signatures are manifested by some carbonates with light oxygen $(-6.4 \%$ to $-6.8 \%$ o $)$ and radiogenic strontium isotopes ( 0.70957 to 0.71166 ; Sample, unpublished data).

Hole 891A was drilled to 9.9 mbsf, while Hole 891B was drilled to $472 \mathrm{mbsf}$; recovery was 99 percent and 11 percent, respectively (Westbrook, Carson, Musgrave, et al., 1994). Hole 891C was drilled for logging, but was not cored. The sediments recovered at this site are dominantly post-middle Pliocene clayey silts and fine to medium sands, although a substantial portion of the unrecovered section may be coarse turbidite sands, as were recovered at Deep Sea Drilling Project (DSDP) Site 174 (Kulm, von Huene et al., 1973). Sheared fabrics and polished and slickenlined surfaces indicated three fault zones at 225, 263, and 375 mbsf (Tobin et al., this volume); the last two are also reflected by discontinuities in the bulk density distribution (Fig. 2). In addition, bulk density discontinuities suggest fault zones at 308 and 440 mbsf (Fig. 2; Moran et al., this volume). Recent lateral flow of fluids is suggested by the presence of $\mathrm{C}_{2+}$ hydrocarbons at horizons of $314,340,367$, and 410 mbsf (Whiticar et al., this volume). The most significant discontinuities in the inorganic chemical profiles occur at 200, 300 to 320 , and 440 mbsf (Westbrook, Carson, Musgrave, et al., 1994). There is also a distinct difference in pore-water chemistry between Holes $891 \mathrm{~A}$ and $891 \mathrm{~B}$. The pore fluids of $891 \mathrm{~A}$, drilled only to a depth of 9.9 mbsf, do not show steady-state profiles with presumed bottom-water chemistry at this site, but are more similar to pore-water chemistry from depths greater than 200 mbsf in Hole 891B. Considered as a whole, the data suggest that the most active hydrogeological horizons occur between 410 and 440 mbsf and between 300 and 320 mbsf. In addition, the difference in geochemistry between Holes 891A and 891B indicates that substantial differences in pore-fluid chemistry are possible over small distances. The prominent seismic reflector observed at $375 \mathrm{mbsf}$ may have been an active fault, as suggested by structures and discontinuities in the physical properties, but there is no chemical evidence that it is currently an active fluid conduit.

\section{Site 892}

Site 892 is located approximately $350 \mathrm{~m}$ east of a bioherm that was previously investigated with the Alvin, which provided evidence that abundant carbonate is forming from seepage of fluids at the surface. Isotopic signatures of the carbonates suggest that fluid sources are dominantly shallow, although some advection of deep fluids cannot be ruled out (Sample and Reid, in press). The oxygen and strontium isotope compositions are consistent with values expected for carbonates forming under conditions found at the sea floor in the bio- herm $\left(\delta^{18} \mathrm{O}=+3 \%\right.$ to $+10 \%{ }^{8}{ }^{87} \mathrm{Sr} /{ }^{86} \mathrm{Sr}=0.70857$ to 0.70909$)$. Carbon isotopes $\left(\delta^{13} \mathrm{C}=-55 \%\right.$ to $-38 \%$ ) can also be explained by shallow processes involving oxidation of biogenic methane and carbon dioxide evolved from fermentation; however, thermogenic methane cannot be eliminated as a carbon source.

Five holes at Site 892 were drilled at about $670 \mathrm{mbsl}$, but only Holes 892A, 892D, and 892E were cored. Hole 892A was cored continuously to $176.5 \mathrm{mbsf}$, Hole $892 \mathrm{D}$ from 0 to $77 \mathrm{mbsf}$ and 100 to $166.5 \mathrm{mbsf}$, and Hole $892 \mathrm{E}$ only sporadically to $62 \mathrm{mbsf}$ (Westbrook, Carson, Musgrave, et al., 1994). The location of the site was chosen to study the nature of the bottom-simulating reflector (BSR) and to investigate fluid flow related to the seismically-imaged fault. The BSR at this location appears to dome upward along the fault; this observation was used to suggest that warm fluids migrating from depth are pushing up the base of the gas hydrate in this region (Westbrook, Carson, Musgrave, et al., 1994). A prominent east-side-up scarp appears where the fault reaches the sea floor, providing evidence that the thrust is tectonically, as well as hydrogeologically, active (Westbrook, Carson, Musgrave, et al., 1994). In Hole 892A the depth of the BSR was $72 \mathrm{mbsf}$, and the prominent fault imaged on seismic reflection profiles was penetrated at about 105 mbsf.

Core recovery at Holes $892 \mathrm{~A}$ and $892 \mathrm{D}$ was 35 and 53 percent, respectively (Fig. 3). The sediments are dominantly late Miocene to Pleistocene silty clays and clayey silts (Camerlenghi et al., this volume; Fourtanier, this volume; Caulet, this volume; Zellers, this volume) and are probably abyssal plain deposits similar to those encountered at the base of DSDP Hole 174. Sand layers tend to be more common above $67.8 \mathrm{mbsf}$, and a prominent gravel layer occurs in both holes at $68 \mathrm{mbsf}$. Many sands are rich in quartz and feldspar and contain significant amounts of volcanic glass; other sands are rich in glaucony. Bulk X-ray diffraction (XRD) analyses indicate that clay minerals are dominantly chlorite, illite, and mixed layer smectite-illite (Westbrook, Carson, Musgrave, et al., 1994).

Cores from Hole 892A exhibit three main structural domains (Fig. $3)$ : domain I ( $0-52 \mathrm{mbsf}$ ) has moderately steep bedding dips, domain II (52-106 mbsf) has bedding dips of only $10^{\circ}$ to $20^{\circ}$, and domain III (106 to $175 \mathrm{mbsf}$ ) is dominated by stratal disruption and a scaly fabric (Tobin, this volume). In addition, there is structural evidence for significant faults or fault zones in Hole 892A at 52, 62.5-67, and 116147 mbsf. The faults at 52 and 116 to 147 mbsf correlate approximately with stratigraphic inversions recognized at 45-50 and 107$117 \mathrm{mbsf}$ (Fourtanier, this volume). A stratigraphic inversion in Hole 892D occurs between 76 and 110 mbsf. Sharp porosity decreases occur at $67.8,104,144$, and 164 mbsf and probably are caused by faultrelated strain and consolidation.

The average geothermal gradient in Hole $892 \mathrm{~A}$ is $51^{\circ} \mathrm{C} / \mathrm{km}$, but positive temperature anomalies of $1.6^{\circ} \mathrm{C}$ and $2.5^{\circ} \mathrm{C}$ occur at 67.5 and 87.5 mbsf, respectively (Westbrook, Carson, Musgrave, et al., 1994). 


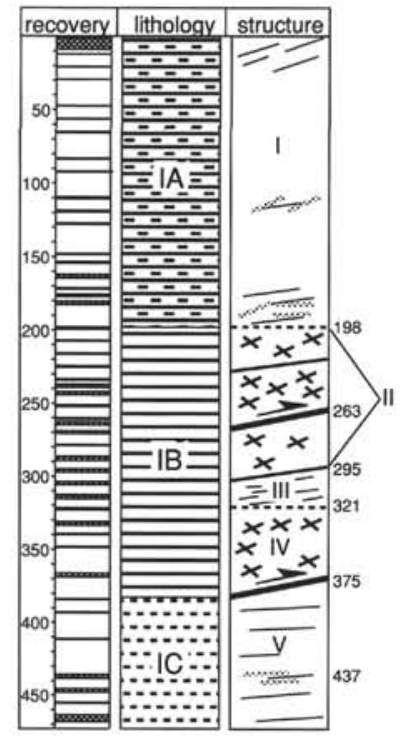

\section{Site 891}
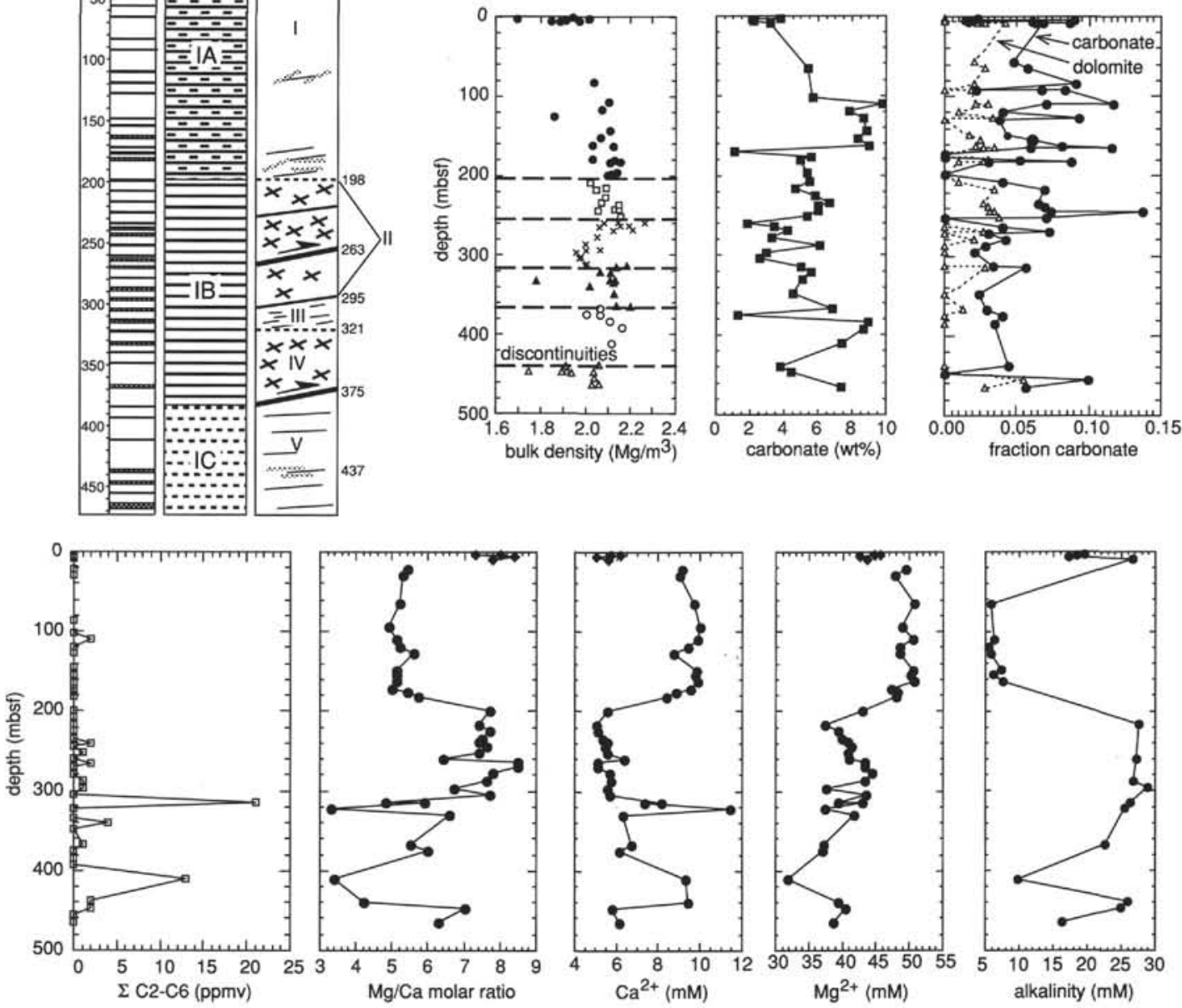

Figure 2. Summary of lithology, physical properties, carbonate content, and selected pore fluid chemistry for Site 891 . Data above $10 \mathrm{mbsf}$ are from Hole $891 \mathrm{~A}$, the rest are from Hole 891B. Faults occur at 225, 263, 295, 375, and $\sim 430 \mathrm{mbsf}$. Inferred discontinuities in bulk densities are shown as dashed lines. For more detailed discussion of lithology, structure, and organic geochemistry, see Camerlenghi et al. (this volume), Tobin et al. (this volume), Moran et al. (this volume), and Whiticar et al. (this volume). Weight percent carbonate determined by shipboard coulometric analysis. Fraction carbonate determined by shorebased XRD analysis of dolomite and calcite peak heights relative to standard mixtures of carbonates and clay minerals; carbonate fractions of the bulk sediments are shown as solid circles, dolomite fractions as open triangles, and calcite fractions are the difference. Values of zero signify no measurable carbonate occurs in the bulk sample. Errors in determination are typically from $0 \%-20 \%$ when compared with gravimetric methods, but relative comparisons of carbonate content with XRD technique are accurate.

The narrow localization of the anomalous temperatures suggests that fluid flow has occurred very recently, or the temperature spike would have degraded. The presence of higher hydrocarbons $\left(\mathrm{C}_{2}+\right)$ at horizons of 68 and 126 mbsf in Hole $892 \mathrm{~A}$ and at 107 mbsf in Hole 892D suggest recent migration of deeper fluids at these levels, because the in situ organic matter is not mature enough to have generated the higher hydrocarbons (Whiticar et al., this volume). In addition, the lack of degradation by bacteria of the higher hydrocarbons in the pore waters at these depths is further evidence that flow has occurred recently.

Inorganic geochemical profiles show broad minima in $\mathrm{Cl}^{-}, \mathrm{Na}^{+}$, and $\mathrm{Mg}^{2+}$ centered between 135 and 140 mbsf in Hole 892A; a pronounced maximum in silica occurs at 105 mbsf. These types of concentration anomalies are typical of deep-seated fluids in these environments, suggesting that fluid flow has occurred in the main structural fault zone and in the fault zone at $105 \mathrm{mbsf}$ (Westbrook, Carson, Musgrave, et al., 1994; Kastner et al., this volume).

\section{METHODS}

\section{Determination of Carbonate Content and Composition}

Our carbonate analyses focused mainly on diagenetic cements in samples that were not described as concretions or nannofossil-rich layers. Some samples may contain a biogenic component, but optical examination indicates that this component is relatively small. X-ray diffraction (XRD) patterns were obtained from $20^{\circ}$ to $35^{\circ} 2 \theta$ at $2 \%$ min, using $40 \mathrm{kV}$ accelerating voltage and $20 \mathrm{~mA}$ current with a $\mathrm{Cu}$ $k \alpha$ source. Peak heights in the region of $29.4^{\circ} 2 \theta$ were used to estimate calcite composition and concentration; $31^{\circ} 2 \theta$ was used to characterize dolomite. Quartz was used as an internal standard for peak position. Results from shipboard coulometric analysis and shorebased XRD analysis are presented in Figures 2 and 3 for comparison. Fraction carbonate values reported from XRD analysis represent the fraction of the carbonate in the bulk sample. Concentrations were estimated by comparing peak heights on unknowns to peak heights on 


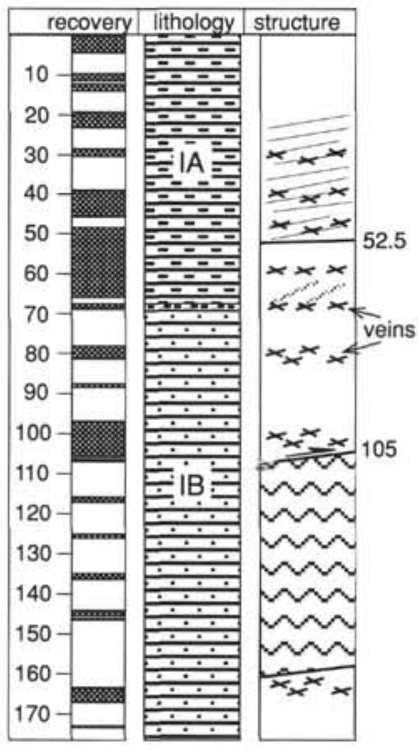

\section{Hole 892A}
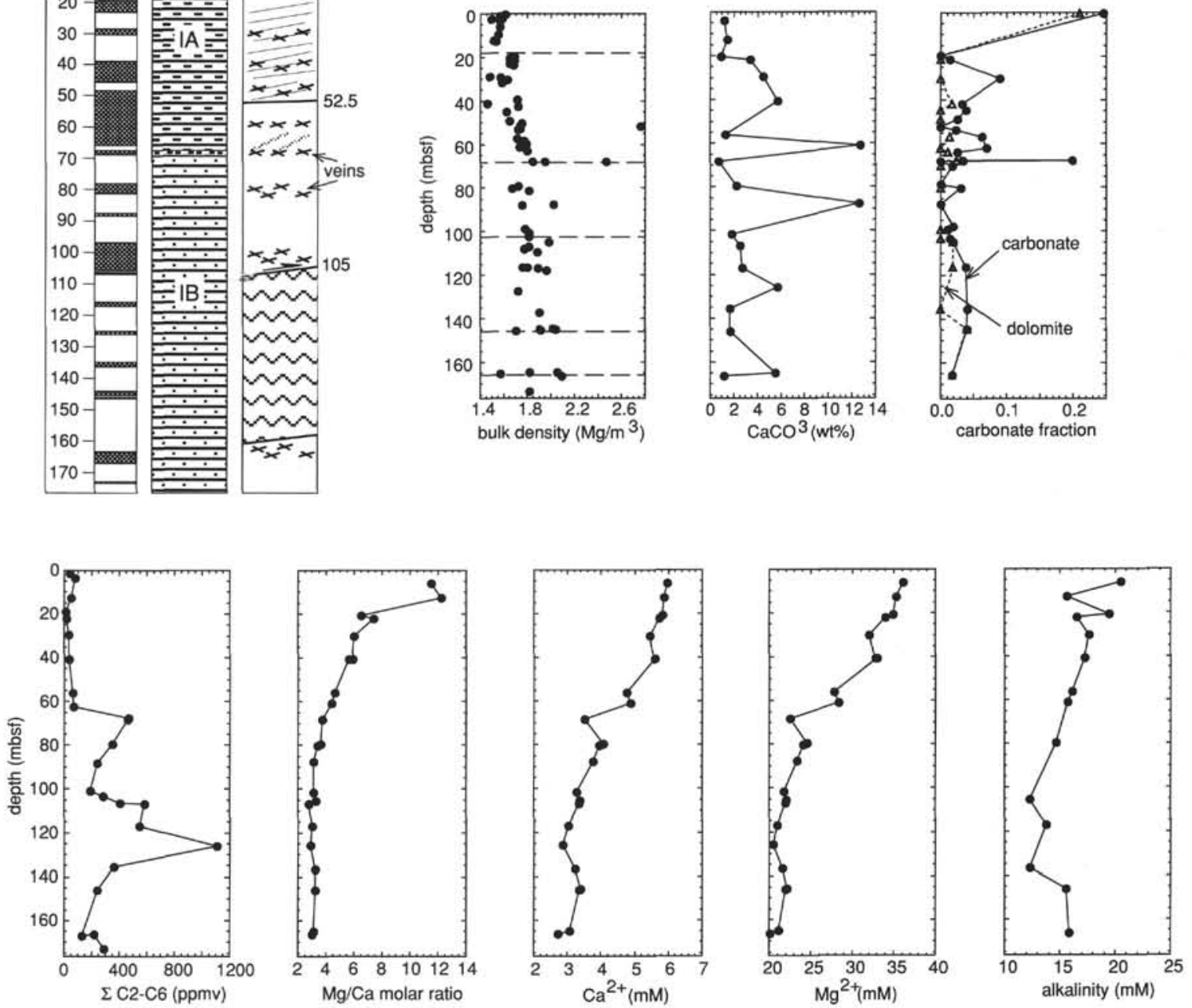

Figure 3. Summary of lithology, physical properties, carbonate content, and selected pore fluid chemistry for Hole 892A. Data from Holes 892E and 892D not shown for clarity. Major faults occur at 52.5, 62.5-67.5, 105, and from 105 to $\sim 160$ mbsf. A gravel layer occurs at the top of lithostratigraphic section IB. See Figure 2 caption for detailed explanation.

carbonate-free sediments from Site 892 spiked with known amounts of carbonate. Errors in absolute concentration estimates are typically $\pm 25 \%$ relative. The XRD method tends to underestimate carbonate content compared to gravimetric analysis, but the technique is reasonably accurate when comparing relative carbonate abundances in a large number of samples through the section. Carbonate contents for all samples analyzed for strontium concentrations were determined by gravimetric methods, and these values were used for calculating strontium concentrations in the carbonates (Table 1).

Fifteen samples at Site 891 were analyzed for the carbon and oxygen isotope compositions of the diagenetic carbonate cements (Table 1). Most analyses were of cements occurring in silty or sandy lithologies, although two mud cements were also analyzed. Twentyseven samples from Holes 892A and 892D were analyzed for the carbon and oxygen isotope compositions of their diagenetic carbonate cements (Table 1). Leaching of carbonates for oxygen and carbon isotopes was done by the technique of McCrea (1950). Samples with a significant component of biogenic carbonate were avoided, but a small biogenic contribution may have been present in some samples. Veins were mechanically separated for analysis with a razor blade or microdrill. Before extraction of $\mathrm{CO}_{2}$, all samples were treated with sodium hypochlorite to remove organic matter, then rinsed and centrifuged three times in distilled water.

All samples analyzed for strontium were rinsed in triply distilled water and dried, then leached with $2 \mathrm{~mL}$ of $1.0 \mathrm{~N}$ acetic acid for 2 hours. The leachate was dried and then dissolved in $2.5 \mathrm{~N} \mathrm{HCl}$ for separation on cation exchange columns. The nine samples from Site 892 were sequentially leached in $0.1 \mathrm{~N}$ and $1.0 \mathrm{~N}$ acetic acid to test for the effects of acid strength on leaching strontium from other sources in the detrital matrix. A split from each leachate was analyzed with an inductively-coupled plasma (ICP) spectrometer to evaluate relative concentration changes of $\mathrm{Mg}^{2+}, \mathrm{Ca}^{2+}, \mathrm{Fe}^{2+}, \mathrm{Al}^{4+}, \mathrm{Sr}^{2+}, \mathrm{Rb}^{-}$, $\mathrm{K}^{-}$, and $\mathrm{Mn}^{2+}$ that might be related to leaching of non-carbonate phases. The only systematic difference noted was that the stronger acid was more effective at dissolving total carbonate (resulting in higher bulk $\mathrm{Sr}^{2+}$ and $\mathrm{Ca}^{2+}$ concentrations) as well as dissolving dolomite (higher bulk $\mathrm{Mg} / \mathrm{Ca}$ ratios in dolomite-bearing samples). Thus, we consider that the $1.0 \mathrm{~N}$ leaches to be more effective, and $1.0 \mathrm{~N}$ acetic acid was used for all of Site 891 samples. Final strontium concentrations were corrected for the carbonate fraction of the bulk sediment. 
Table 1. Geochemical data of carbonate cements.

\begin{tabular}{|c|c|c|c|c|c|c|c|c|c|c|c|c|}
\hline $\begin{array}{l}\text { Core, section, } \\
\text { interval }(\mathrm{cm})\end{array}$ & $\begin{array}{l}\text { Depth } \\
\text { (mbsf) }\end{array}$ & Comments & $\begin{array}{l}\text { Fraction } \\
\text { calcite } \\
\text { (XRD) }\end{array}$ & $\begin{array}{l}\text { Fraction } \\
\text { dolomite } \\
\text { (XRD) }\end{array}$ & $\begin{array}{l}\delta^{13} \mathrm{C} \\
(\mathrm{PDB})\end{array}$ & $\begin{array}{l}\delta^{18} \mathrm{O} \\
(\mathrm{PDB})\end{array}$ & $\begin{array}{l}{ }^{87} \mathrm{Sr} /{ }^{86} \mathrm{Sr} \\
0.1 \mathrm{~N} \text { acetic }\end{array}$ & $2 \sigma$ & $\begin{array}{l}{ }^{87} \mathrm{Sr} /{ }^{86} \mathrm{Sr} \\
1 \mathrm{~N} \text { acetic }\end{array}$ & $2 \sigma$ & $\begin{array}{c}\mathrm{Sr} \\
(\mathrm{ppm})\end{array}$ & ${ }^{87} \mathrm{Sr} r^{86} \mathrm{Sr}^{*}$ \\
\hline \multicolumn{13}{|l|}{ 146-891A- } \\
\hline $1 \mathrm{H}-\mathrm{CC}, 1-5$ & 4.4 & Powdery carbonate & 0.09 & 0.00 & -4.41 & -9.24 & & & 0.71030 & 0.000009 & 238.9 & \\
\hline $10 X-1,43-47$ & 83.5 & Sandy/silty layers & 0.07 & 0.02 & -1.68 & -11.44 & & & & & & \\
\hline $14 X-1,18-22$ & 109.7 & Sandy mud & 0.10 & 0.02 & -3.96 & -8.59 & & & 0.71128 & 0.000011 & 676.4 & \\
\hline $14 X-1,85-89$ & 110.4 & Contorted layers & 0.04 & 0.03 & -0.98 & -11.49 & & & & & & \\
\hline $16 \mathrm{X}-1,84-86$ & 128.1 & Cemented sand & 0.04 & 0.00 & -0.97 & -11.67 & & & & & & \\
\hline $20 \mathrm{X}-1,79-84$ & 163.3 & Mud & 0.09 & 0.03 & -2.52 & -10.17 & & & & & & \\
\hline $20 \mathrm{X}-\mathrm{CC}, 32-36$ & 164.5 & Cemented sand & 0.02 & 0.04 & -1.61 & -12.06 & & & & & & \\
\hline $26 \mathrm{X}-1,25-30$ & 207.4 & Gray silty pod & 0.03 & 0.01 & -2.73 & -8.74 & & & & & & \\
\hline $31 \mathrm{X}-\mathrm{CC}, 22-27$ & 244.3 & Silty mud & 0.11 & 0.03 & -3.32 & -7.44 & & & 0.71048 & 0.000011 & 250.4 & \\
\hline $34 X-1,16-18$ & 263.3 & Silty and sandy & 0.04 & 0.00 & -0.83 & -6.13 & & & & & & \\
\hline $34 X-1,16-18$ & 264.0 & Shell fragments & & & -1.66 & -2.12 & & & & & & \\
\hline $41 X-1,16-21$ & 313.0 & Silty mud & 0.03 & 0.00 & -2.23 & -9.19 & & & 0.70990 & 0.000009 & 444.1 & \\
\hline $41 X-2,81-83$ & 315.1 & Silty sand & 0.03 & 0.03 & -1.52 & -7.41 & & & & & & \\
\hline $48 \mathrm{X}-\mathrm{CC}, 21-23$ & 375.7 & Sand & 0.04 & 0.00 & -1.50 & -12.22 & & & 0.71155 & 0.000011 & 559.2 & \\
\hline $57 X-1,2-8$ & 454.7 & Silty sand & 0.04 & 0.06 & -1.71 & -7.70 & & & & & & \\
\hline $\begin{array}{l}58 \mathrm{X}-2,44-48 \\
146-892 \mathrm{~A}-\end{array}$ & 464.9 & Coarse sand & 0.03 & 0.03 & -4.30 & -16.55 & & & 0.71058 & 0.000008 & 612.5 & \\
\hline $3 X-2,99-101$ & 21.5 & Vug filling & 0.24 & 0.00 & -28.43 & 5.80 & & & & & & \\
\hline $6 X-2,107-111$ & 41.6 & Mud & 0.02 & 0.02 & 25.50 & 10.70 & & & & & & \\
\hline $8 X-3,90-92$ & 61.9 & Mud & 0.07 & 0.00 & 1.28 & 2.80 & & & & & & \\
\hline $9 \mathrm{X}-1,20-22$ & 67.7 & Hard sandstone & 0.17 & 0.03 & 0.23 & -12.48 & 0.70611 & 0.000010 & 0.70576 & 0.000010 & 22.8 & 0.70592 \\
\hline $11 X-2,57-59$ & 80.1 & $\begin{array}{l}\text { Concretion, shear } \\
\text { bands }\end{array}$ & 0.00 & 0.33 & 7.88 & 4.39 & & & & & & \\
\hline $13 X-4,30-34$ & 99.1 & Fractured mud & 0.01 & 0.00 & -1.90 & 0.70 & & & & & & \\
\hline $13 X-7,132-137$ & 103.3 & Consolidated mud & 0.01 & 0.00 & 4.66 & 3.30 & & & & & & \\
\hline $15 X-1,4-5$ & 116.0 & Concretion & 0.25 & 0.00 & -30.38 & 5.59 & & & & & & \\
\hline $18 X-1,42-44$ & 144.9 & $\begin{array}{l}\text { Concretion, shear } \\
\text { bands }\end{array}$ & 0.00 & 0.36 & 10.35 & 3.98 & & & & & & \\
\hline \multicolumn{13}{|l|}{ 146-892D- } \\
\hline $4 X-1,146-148$ & 29.0 & Pelagic(?) mud & 0.27 & 0.02 & 12.29 & 4.18 & 0.70786 & 0.000010 & 0.70776 & 0.000010 & 10.4 & 0.70781 \\
\hline $6 \mathrm{X}-3,88-90$ & 50.1 & Concretion & 0.17 & 0.04 & -13.10 & 4.58 & & & & & & \\
\hline $6 \mathrm{X}-3,100-102$ & 50.3 & Carbonate layer & 0.18 & 0.07 & -20.66 & 4.63 & 0.70878 & 0.000010 & 0.70885 & 0.000011 & 112.2 & 0.70884 \\
\hline $6 \mathrm{X}-3,121-123$ & 50.5 & Concretion & 0.24 & 0.00 & -22.32 & 4.17 & & & & & & \\
\hline $7 X-3,133-136$ & 58.1 & Concretion & 0.03 & 0.04 & 0.58 & 1.48 & & & & & & \\
\hline $8 \mathrm{X}-\mathrm{CC}, 12-17$ & 66.7 & & 0.72 & 0.00 & -8.33 & -14.35 & 0.70720 & 0.000009 & 0.70712 & 0.000010 & 16.2 & 0.70715 \\
\hline $8 \mathrm{X}-\mathrm{CC}, 20-25$ & 66.8 & Vein fragments & 0.06 & 0.03 & -2.52 & -11.29 & & & & & & \\
\hline $9 X-1,56-59$ & 69.9 & Mud with boudins & 0.02 & 0.00 & -4.48 & -8.83 & & & & & & \\
\hline $9 X-1,81-84$ & 70.1 & Cemented boudins & 0.12 & 0.03 & -3.00 & -8.20 & 0.70675 & 0.000010 & 0.70670 & 0.000011 & 49.2 & 0.70672 \\
\hline $9 X-3,87-89$ & 72.5 & Carbonate layer & 0.07 & 0.03 & -1.08 & -9.87 & 0.71122 & 0.000009 & 0.71192 & 0.000011 & 75.1 & 0.71140 \\
\hline $9 X-5,68-69$ & 74.2 & & 0.00 & 0.57 & 11.23 & 6.35 & & & & & & \\
\hline $10 X-1,64-68$ & 100.6 & $\begin{array}{l}\text { Brecciated } \\
\text { concretion }\end{array}$ & 0.04 & 0.00 & -0.17 & -7.34 & 0.70667 & 0.000010 & 0.70685 & 0.000009 & 99.8 & 0.70676 \\
\hline $10 \times-4,67-69$ & 104.4 & & & & -4.28 & -9.50 & & & & & & \\
\hline $10 X-5,98-100$ & 106.2 & Veined concretion & 0.57 & 0.00 & 1.18 & -3.27 & & & & & & \\
\hline $10 X-5,98-100$ & 106.2 & & 1.00 & 0.00 & 4,02 & -7.08 & & & & & & \\
\hline $12 X-3,14-18$ & 122.1 & Carbonate layer & & & 11.74 & 4.75 & 0.70801 & 0.000008 & 0.70802 & 0.000010 & 20.1 & 0.70801 \\
\hline 13X-CC, $13-19$ & 128.6 & Cemented sand & 0.02 & 0.00 & -1.99 & -11.23 & 0.70720 & 0.000009 & 0.70657 & 0.000010 & 36.5 & 0.70687 \\
\hline $14 \mathrm{X}-\mathrm{CC}, 29-31$ & 140.0 & Cemented sand & 0.00 & 0.30 & 6.61 & -0.99 & & & & & & \\
\hline
\end{tabular}

Note: * values are weighted averages of 0.1 and $1.0 \mathrm{~N}$ leaches.

The ${ }^{87} \mathrm{Sr}{ }^{86} \mathrm{Sr}$ ratio of standard NBS 987 was $0.71026 \pm 3(2 \sigma)$. Final strontium isotope ratios of Site 892 samples are plotted as weighted averages of the $0.1 \mathrm{~N}$ and $1.0 \mathrm{~N}$ leaches, unless otherwise noted.

\section{RESULTS}

\section{Site 891}

\section{Carbonate Content}

Diagenetic carbonate concretions with high carbonate contents were distributed randomly throughout the cores (Westbrook, Carson, Musgrave, et al., 1994). In the rest of the sediments, diagenetic porefilling cement is preserved as dispersed rhombs of dolomite and calcite (Plate 1; Westbrook, Carson, Musgrave, et al., 1994). Carbonate content in the samples analyzed by coulometric analysis ranges from $1 \%$ to $10 \%$, whereas XRD estimates (excluding concretions and fossiliferous layers) range from $0 \%$ to $14 \%$ (Fig. 2). Calcite or magnesian calcite is present in all carbonate-bearing samples and is the dominant carbonate in the section. Below 260 mbsf, most of the sam- ples analyzed contain little or no dolomite. Dolomite becomes an important constituent again in samples from below $440 \mathrm{mbsf}$, which also corresponds to a possible increase in total carbonate concentration.

Variations in carbonate concentration do not appear to correlate on a gross scale with variations in the pore fluid profiles of alkalinity, $\mathrm{Mg}, \mathrm{Ca}$, or $\mathrm{Mg} / \mathrm{Ca}$. Depth profiles of dissolved constituents are ragged, perhaps due to the coarse lithology and "leaky" fluid conduits (Fig. 2; Westbrook, Carson, Musgrave, et al., 1994). Alkalinity is generally low between 10 and $200 \mathrm{mbsf}$, which corresponds roughly with high carbonate content and may reflect an influence of carbonate precipitation (Fig. 2). Mg and Ca both drop abruptly below $200 \mathrm{mbsf}$, while carbonate content shows variable increases and decreases, suggesting $\mathrm{Mg}$ and $\mathrm{Ca}$ concentrations are controlled by other processes. Changes in the $\mathrm{Mg} / \mathrm{Ca}$ ratio of the pore fluids tend to show a negative correlation with changes in the ratio of dolomite to calcite in the solids. Thus, the increased $\mathrm{Mg} / \mathrm{Ca}$ ratio below $200 \mathrm{mbsf}$ does not appear to have caused an increase in dolomite precipitation or recrystallization of calcite to dolomite. The general lack of correlation between carbonate content and pore fluid chemistry suggests that the cements 
reflect past chemical characteristics of the pore fluids that are not present today.

The sediment intervals where fluid conduits were inferred from the presence of higher hydrocarbons appear to correspond to dolomite-bearing sequences ( 314 and $367 \mathrm{mbsf}$ ). At horizons where faults or fluid conduits were recognized based on structural or physical property data, but did not contain higher hydrocarbons, the carbonates are characteristically calcite (263, 375, and $440 \mathrm{mbsf})$.

\section{Stable Isotope Data}

Carbon isotopes from diagenetic carbonates at Site 891 (Fig. 4) show a relatively narrow range $\left(\delta^{13} \mathrm{C}=-4.4 \%\right.$ o to $-0.8 \%$ o), while oxygen values show a much larger range $\left(\delta^{18} \mathrm{O}=-16.5 \%\right.$ to $-6.2 \%$ ); a similar range of stable isotopes has been observed previously in cements recovered from the Oregon margin (Kulm and Suess, 1990; Ritger et al., 1987; Sample and Reid, in press). The carbon isotopes are typical for marine carbonates precipitated from seawater; however, a carbon reservoir dominated by other sources could give similar values. For example, the diagenetic carbon may be derived from recrystallized biogenic carbonate or from fermentation reactions combining carbon dioxide and oxidized methane as a carbon source (Claypool and Kaplan, 1974). Fermentation reactions probably become dominant below the zone of sulfate reduction at $200 \mathrm{mbsf}$.

The oxygen values are more problematic and are certainly different than values expected of biogenic carbonate. Light oxygen in this environment can be derived from hydration reactions such as the formation of clay minerals from volcanic glass, from infiltration of meteoric fluids, or from crystallization of the carbonate at relatively high fluid temperatures (Sample and Reid, in press).

A plot of isotopes vs. depth shows relatively smooth profiles for both carbon and oxygen (Fig. 5). Oxygen isotopes decrease slightly to a depth of about $185 \mathrm{mbsf}$, then increase to a small maximum at 263 mbsf, which corresponds to the depth of a fault horizon (Tobin et al., this volume). Oxygen isotope values then generally decrease again sharply to a minimum value of $-16.5 \%$ near the bottom of the hole. Because the oxygen isotope profile does not decrease steadily with depth and increasing burial temperature, the carbonates do not represent cements that formed in equilibrium with current downhole temperature conditions. Although temperature measurements were

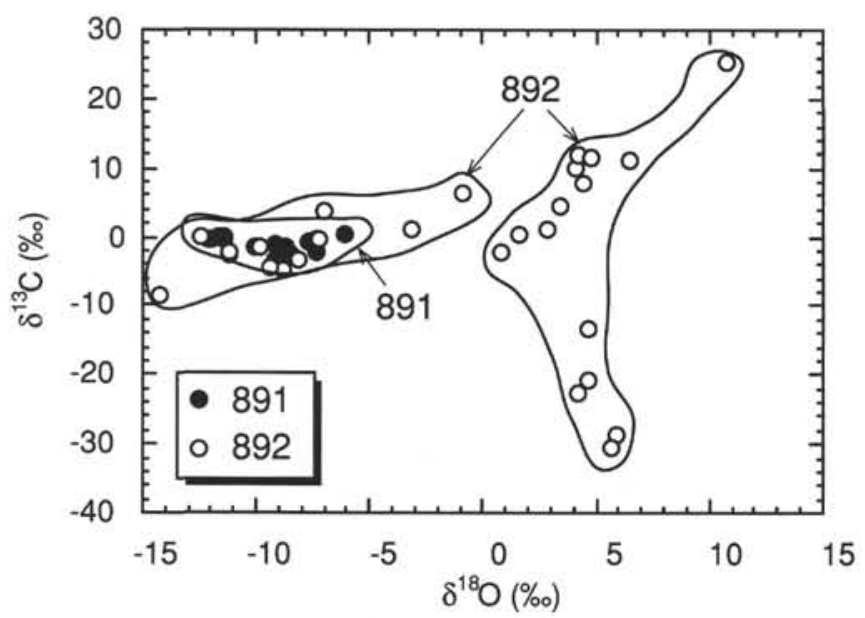

Figure 4. Carbon and oxygen isotopes from carbonates, Sites 891 and 892. All values are quoted relative to the PDB standard. Precision of values is $\pm 0.1 \%$ for oxygen and carbon. not successful at Site 891, consideration of typical geothermal gradients from the margin suggests that temperatures are less than $30^{\circ} \mathrm{C}$ at the bottom of Hole $891 \mathrm{~B}$. In addition, $\delta^{18} \mathrm{O}_{\mathrm{Smow}}$ values of the pore fluids range from $-0.1 \%$ o to $-1.3 \%$ (Kastner and Elderfield, this volume). Apparently temperature and oxygen isotopes of the current pore fluids cannot explain the ${ }^{18} \mathrm{O}$ depletions of the carbonates. It is difficult to evaluate the relationship between the isotopes of the carbonate samples and major faults because of limited sample coverage at these horizons.

\section{Strontium Isotope Data}

Six strontium isotope analyses were obtained from samples at Site 891. All carbonates analyzed are diagenetic cements, but from a variety of lithologies (Table 1). Most strontium isotope values fall in the range between 0.70990 and 0.71155 (Fig. 5), substantially more radiogenic than the value for modern seawater. Based on the data available, there is also no systematic trend in the isotope ratios with depth. The carbonates from Site 891 have ${ }^{87} \mathrm{Sr} /{ }^{86} \mathrm{Sr}$ ratios much higher than ratios from Site 892 , and are more similar to radiogenic strontium isotopes that were observed in diagenetic carbonates near the deformation front farther to the north (Sample and Reid, in press). Strontium concentrations are moderate and well within the range of concentrations typically observed in carbonates (Table 1) (Veizer, 1983). A strontium mixing diagram suggests mixing between two endmembers: a radiogenic phase with high strontium concentrations, and a moderately radiogenic phase with lower strontium concentrations, but the diagram shows significant scatter (Fig. 6). The five deepest samples display two apparent trends of a repeated increase of ratios with depth; more data are needed to evaluate whether these trends are robust, however. The most radiogenic carbonate analyzed occurs in a

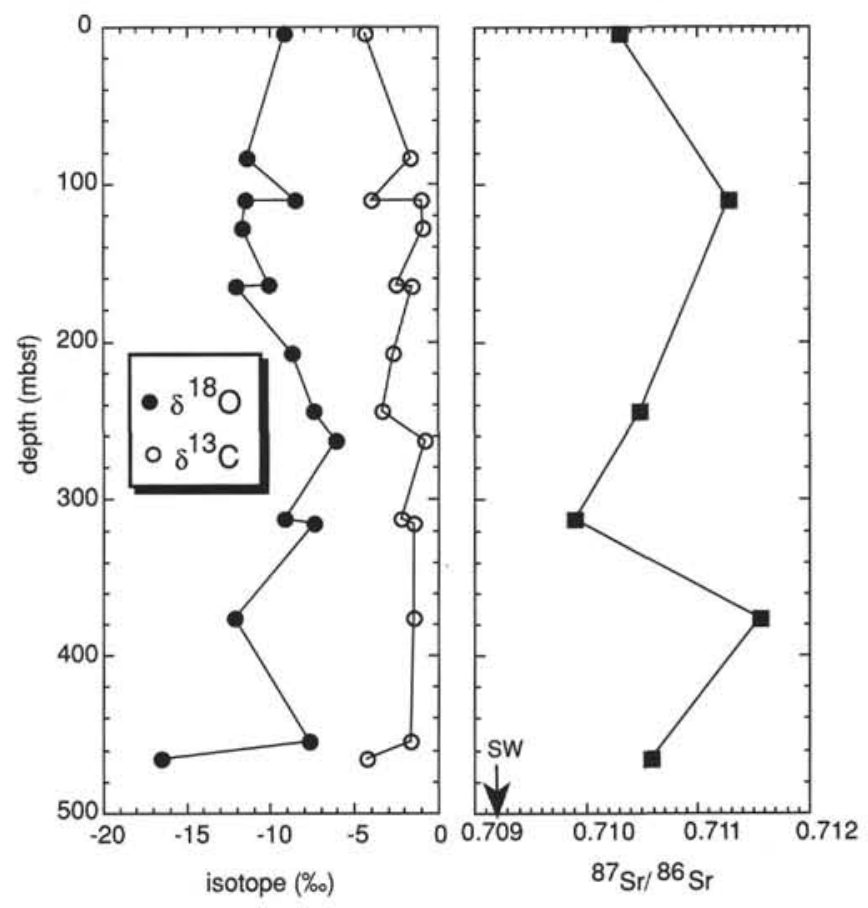

Figure 5. Carbon, oxygen, and strontium isotopes from carbonates vs. depth for Site 891. Samples prepared for strontium analysis by leach for carbonate fraction with $1.0 \mathrm{~N}$ acetic acid. "SW" denotes average modern seawater value. Symbols are larger than analytical errors. 


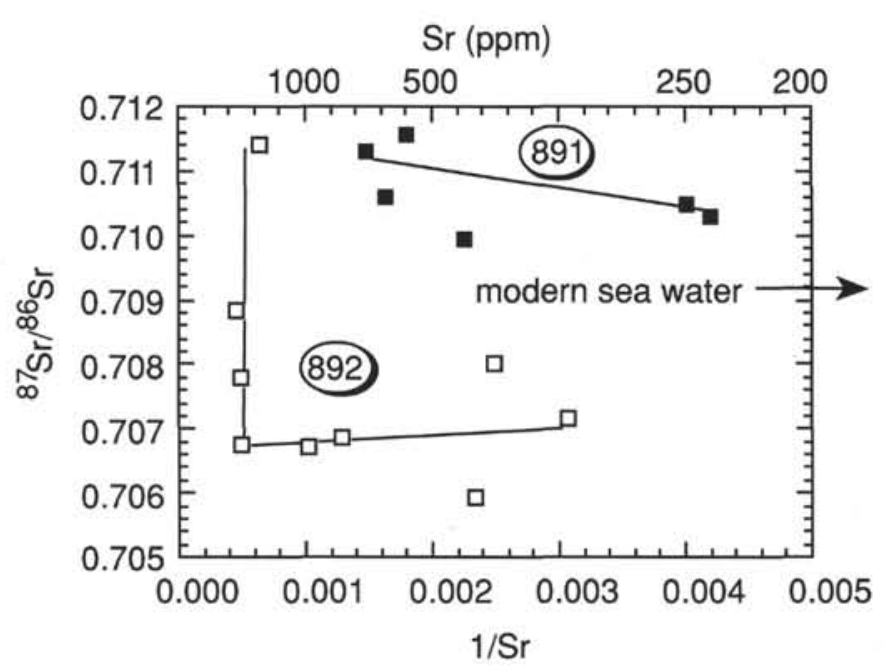

Figure 6. Strontium mixing diagram, Sites 891 and 892. Possible two-component and three-component mixing trends are shown for 891 and 892 , respectively. Results for Site 892 are from weighted mean of 0.1 and $1.0 \mathrm{~N}$ acetic acid leaches of sediment. Modern seawater would plot off scale to the right of the diagram $\left({ }^{87} \mathrm{Sr} /{ }^{86} \mathrm{Sr}=0.7092\right.$, concentration $\left.=7 \mathrm{ppm}\right)$.

poorly consolidated sand collected from a depth of $375.7 \mathrm{mbsf}$ (146$891 \mathrm{~B}-48 \mathrm{X}-\mathrm{CC}, 21-23 \mathrm{~cm}$ ), the horizon that coincides with the main fault imaged on seismic reflection profiles.

\section{Site 892}

\section{Carbonate Content}

The carbonate content of Site 892 generally is higher than was found at Site 891; some sandstones at Site 892 contain $25 \%$ carbonate cement (Fig. 3). Carbonates occur in the cores as patches, concretions, concretion fragments, cemented silty layers, pore-filling cements in sandstones, veins, and nannofossil oozes (Westbrook, Carson, Musgrave, et al., 1994). The fragments tended to be concentrated at the tops of cores and probably represent concretions reworked by drilling. One of the veins analyzed contains multiple generations of carbonate, with both fibrous and blocky sparite textures (Plate 1). There is a large drop-off in carbonate content at about $72 \mathrm{mbsf}$, which corresponds approximately to the depth of the BSR and the depth of a prominent gravel layer (Fig. 3). Below this depth, carbonate composes less than 5\% of the samples analyzed, and few samples contain appreciable dolomite. The main shear zone (105 to $160 \mathrm{mbsf}$ ) has relatively low carbonate concentrations. Concentrations are elevated, however, in a fault zone recognized between 62 and $68 \mathrm{mbsf}$. This is also the horizon of an observed temperature anomaly and elevated concentrations of higher hydrocarbons (Foucher et al., this volume; Whiticar et al., this volume).

Carbonate compositions at Site 892 show a better correlation with pore fluid profiles than was observed at Site 891. Dolomite concentrations are highest in the upper part of the section, where $\mathrm{Mg} / \mathrm{Ca}$ ratios were also observed to be highest in the pore fluids (Fig. 3). However, the lower boundary of dolomite content shows a sharp drop at a depth of about $74 \mathrm{mbsf}$, while the $\mathrm{Mg} / \mathrm{Ca}$ ratio shows a steadier decrease. At Site 892 the highest concentrations of carbonate occur in the upper part of the section, where alkalinities are also highest, suggesting increased alkalinities may influence carbonate precipitation. Alkalinities show a relatively steady decrease to a depth of 100 mbsf, however, while carbonate contents are relatively constant until a depth of 72 mbsf, where they fall off sharply.

\section{Stable Isotope Data}

The ranges in values of both stable isotopes at Site 892 are larger than those observed for Site 891. The data fall along two trends (Fig. $4)$. One trend shows a relatively narrow range of carbon values centered around zero (most from $-7 \%$ to $+4 \%$ ) and a larger range in ${ }^{18} \mathrm{O}$ depleted oxygen isotopes $(-14 \%$ to $-1 \%$ ) , similar to the data recorded from Site 891 . The second trend shows a relatively narrow range in ${ }^{18} \mathrm{O}$-enriched oxygen isotopes $(0 \%$ to $+7 \%$ ) , but a large range in carbon isotopes $(-30 \%$ to $+12 \%$ ). In addition, one point is an outlier with extreme enrichments in carbon $(+25.5 \%)$ and oxygen $(+10.7 \% 0)$. The second trend is similar to stable isotope characteristics of carbonates collected from the bioherm at the sea floor (Sample and Reid, in press). The outlier may reflect precipitation in the zone of carbonate reduction (Claypool and Kaplan, 1974) below the zone of sulfate exhaustion (below $10 \mathrm{mbsf}$ ).

A plot of carbon isotopes with depth shows that the most strongly ${ }^{13} \mathrm{C}$-depleted samples were collected above $51 \mathrm{mbsf}$ (Fig. 7). One exception is Sample 146-892A-15X-1, 4-5 cm, located at $116 \mathrm{mbsf}$; this is a concretion that was collected near the top of Core 146-892A$15 \mathrm{X}$ and may have fallen from higher in the hole. The depth of 50 mbsf was recognized as a fault zone based on a stratigraphic inversion, and a change in bedding dip. Below this depth, the carbon isotope values are less variable and are restricted to a range of $-10 \%$ o to $+10 \%$. A plot of oxygen isotopes with depth shows the opposite tendency in ranges of values (Fig. 7); most samples above $62 \mathrm{mbsf}$ are restricted to a range of $+1 \%$ to $+6 \%$, whereas below this depth the values range from $-14 \%$ o to $+6 \%$. The strongest depletions in ${ }^{18} \mathrm{O}$ occur in carbonates from depths of $67-75,100-105$, and $128 \mathrm{mbsf}$. The first interval corresponds to a fault zone and fluid conduit which was recognized between 62 and $68 \mathrm{mbsf}$ based on structural features, a bulk density increase, a temperature anomaly, and the presence of higher hydrocarbons (Fig. 3; Foucher et al., this volume; Moran et al., this volume; Tobin et al., this volume; Whiticar et al., this volume). Three of the samples analyzed from this depth interval contained tectonic boudins or veins. The second interval of ${ }^{18} \mathrm{O}$-depleted carbonates corresponds to a fault and fluid conduit recognized from structural features, a porosity decrease, higher hydrocarbons, and pore fluid chemical anomalies (Westbrook, Carson, Musgrave, et al., 1994). All of the depleted samples from this depth are either veins or veined concretions. The sample from $128 \mathrm{mbsf}\left(\delta^{18} \mathrm{O}=-11.2 \%\right)$ lies within the interval of scaly fabric development and numerous geochemical anomalies (Tobin et al., this volume; Kastner et al., this volume). This sample is a cemented sandstone that did not show major tectonic structures, however.

\section{Strontium Isotope Data}

Eighteen strontium isotope analyses were obtained from nine samples at Site 892 (Fig. 7). Most strontium isotope values fall in the range between 0.70576 and 0.70885 ; this is substantially less than the value for modern seawater (0.7092), and many samples have strontium isotope compositions less radiogenic than early Oligocene seawater (DePaolo and Ingram, 1985). The strontium source for these carbonates must include nonradiogenic strontium-bearing phases in the sediment. Pore fluids from Site 892 have ${ }^{87} \mathrm{Sr} /{ }^{86} \mathrm{Sr}$ ratios ranging from 0.70709 to 0.70888 (Kastner and Elderfield., this volume). The carbonate sample with a ratio of 0.71140 was collected from a layer described as a nannofossil ooze (Sample 146-892D-9X-3, 87-89 $\mathrm{cm})$. Clearly this sample cannot be dominated by biogenic carbonate, but must contain abundant diagenetic carbonate with a radiogenic strontium source. This source may be either the North American continent or radiogenic phases within in the sediment.

Strontium concentrations from Site 892 carbonates range from 325 to $2245 \mathrm{ppm}$ (Table 1). The higher end of the range is typical of 
Figure 7. Carbon, oxygen, and strontium isotopes from carbonates vs. depth for Site 892. For most strontium isotope analyses, differential leaching has little effect on isotope ratio.
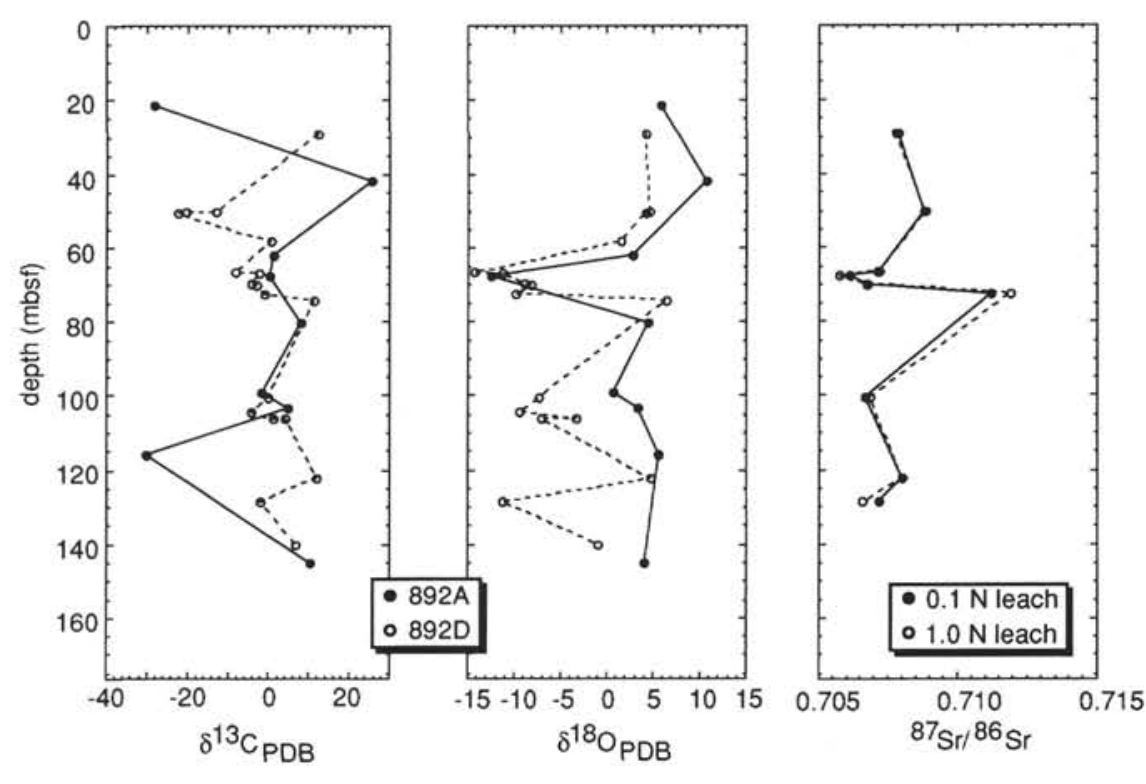

concentrations found in foraminifers (DePaolo and Ingram, 1985), raising the possibility that the acid leaches were dominated by a biogenic component. If true, the carbonates with the highest strontium concentrations should also have ${ }^{87} \mathrm{Sr} /{ }^{86} \mathrm{Sr}$ ratios similar to seawater values over approximately the last nine million years $(0.7090$ to 0.7092). The data show, however, that cements with high strontium concentrations have isotope ratios either much higher or much lower than recent seawater (Samples 146-892D-4X-1, 146-148 cm, -8X$\mathrm{CC}, 12-17 \mathrm{~cm}$, and $-10 \mathrm{X}-1,64-68 \mathrm{~cm})$. That suggests that the dominant control on the strontium reservoir for the cements is not biogenic carbonate. A strontium mixing diagram shows three possible characteristic endmembers, although the data are somewhat scattered (Fig. 6). Two of the endmembers have high strontium concentrations, but both low and high ${ }^{87} \mathrm{Sr} /{ }^{86} \mathrm{Sr}$ ratios. The third endmember has a low ${ }^{87} \mathrm{Sr} /{ }^{86} \mathrm{Sr}$ ratio and low strontium concentration.

A strontium isotope profile of carbonates with depth shows two main features (Fig. 7). Above $65 \mathrm{mbsf}$, the isotope ratios tend to be more radiogenic than in the rest of the column. The most radiogenic carbonate is from a depth of $72.5 \mathrm{mbsf}$, which is the approximate depth of the BSR and just below the depth of a prominent fault zone and inferred fluid conduit. The samples within the main fault zone (105 to $160 \mathrm{mbsf}$ ), including a sample with broken formation and a cemented sandstone, show relatively nonradiogenic strontium isotope ratios. A carbonate vein sample from a depth of $66.7 \mathrm{mbsf}$ in Hole 892 D has a ratio of 0.70715 (Sample 146-892D-8X-CC, 12-17 $\mathrm{cm}$ ), indicating that fluids migrating within this fault zone are much less radiogenic than seawater.

\section{DISCUSSION}

Previous investigations of carbonate chemistry have been conducted at the Barbados, Peru, and Nankai convergent margins. Carbon and oxygen isotopes of authigenic carbonates show a large range in the different settings. In Barbados, authigenic carbonates are precipitated in the landward ODP Leg 110 Sites 673 and 674 (Vrolijk and Shephard, 1991). Most carbon isotopes of the calcites ( $-2 \%$ to $-26.5 \%$ PDB) are consistent with a local source of oxidized organic carbon produced from sulfate reduction of organic matter combined with recrystallization of biogenic carbonate. A single lighter value $(-31.6 \%)$ suggests input from oxidized methane. Oxygen isotopes from the same calcites suggest input of fluids up to $10^{\circ} \mathrm{C}$ warmer than at present below 340 mbsf in Site 674 (Vrolijk and Shephard, 1991). This depth corresponds approximately to the depth of a biostratigraphically defined thrust fault. At Nankai, most analyzed carbonates are from below 900 mbsf (Kastner et al., 1993). Carbon isotopes are relatively heavy and suggest a source from thermally mature organic matter. Oxygen isotopes range from $-0.3 \%$ to $-14.5 \%$, the lightest values suggesting precipitation at in situ temperatures of $100^{\circ} \mathrm{C}$ to $120^{\circ} \mathrm{C}$. In Peru, carbonates have carbon isotopes that vary from -37.3 to $+19.0 \%$ (Thornburg and Suess, 1990). Most of these fall in a range that is consistent with formation in the zone of sulfate reduction (light carbon) or the zone of carbonate reduction (heavy carbon). The lightest values are probably from oxidized methane of either thermogenic or biogenic origin. The oxygen isotopes range from $+2.7 \%$ to $+6.6 \%$ in dolomitic carbonates, but range as low as $-7.5 \%$ in $\mathrm{Mg}$-calcites. The low values in the latter are attributed to influence of meteoric fluids before the sediments subsided to their current depths. A meteoric interpretation is consistent with the crystallographic textures of the light cements, which show sparry or fibrous textures similar to those observed in some veins from Site 892 in Cascadia (Plate 1). Similar textures were also observed in Leg 110 samples, however, suggesting that such carbonates can also form in pore waters not of meteoric origin (Vrolijk and Shephard, 1991).

There are many lines of evidence for the existence of faults and fluid conduits at discrete horizons of Sites 891 and 892, and the chemistry of carbonate cements is useful to constrain the history and sources of fluid flow at these horizons as well as throughout the sedimentary sections. While poor core recovery at Site 891 precludes detailed correlation of features in the holes with isotope signatures of the carbonate cements, enough cements were recovered to correlate gross features of the section with the hydrogeologic history preserved in cements. The most striking features of carbonate chemistry from Site 891 are the strong depletion of ${ }^{18} \mathrm{O}$ and the presence of radiogenic strontium. The depletion in ${ }^{18} \mathrm{O}$ in the diagenetic carbonates can result from depletion of ${ }^{18} \mathrm{O}$ in the pore waters by processes such as lowtemperature alteration of solids in the sediment matrix or formation of gas hydrate. Depletion can also result from flow of meteoric fluids from the continent to the deformation front, or from precipitation under conditions of elevated fluid temperatures, due to burial or advection of pore fluids from depth toward the surface. Whatever the cause of the depletion, it must be related to conditions that prevailed in the past, because the lowest $\delta^{18} \mathrm{O}_{\text {Smow }}$ observed in pore fluids from the cores were greater than $-2 \%$ (Kastner and Elderfield, this volume).

The most likely hydration reaction resulting in depletion of ${ }^{18} \mathrm{O}$ in the pore fluids is alteration of volcanic matter to clay minerals (Gieskes and Lawrence, 1981). Hydration of glass will form clays with ${ }^{18} \mathrm{O}$-enriched water and leave the residual fluid depleted in ${ }^{18} \mathrm{O}$. Because the main source of glass in the shallow part of the section, where temperature is low, is mafic volcanic matter from the Cascades 

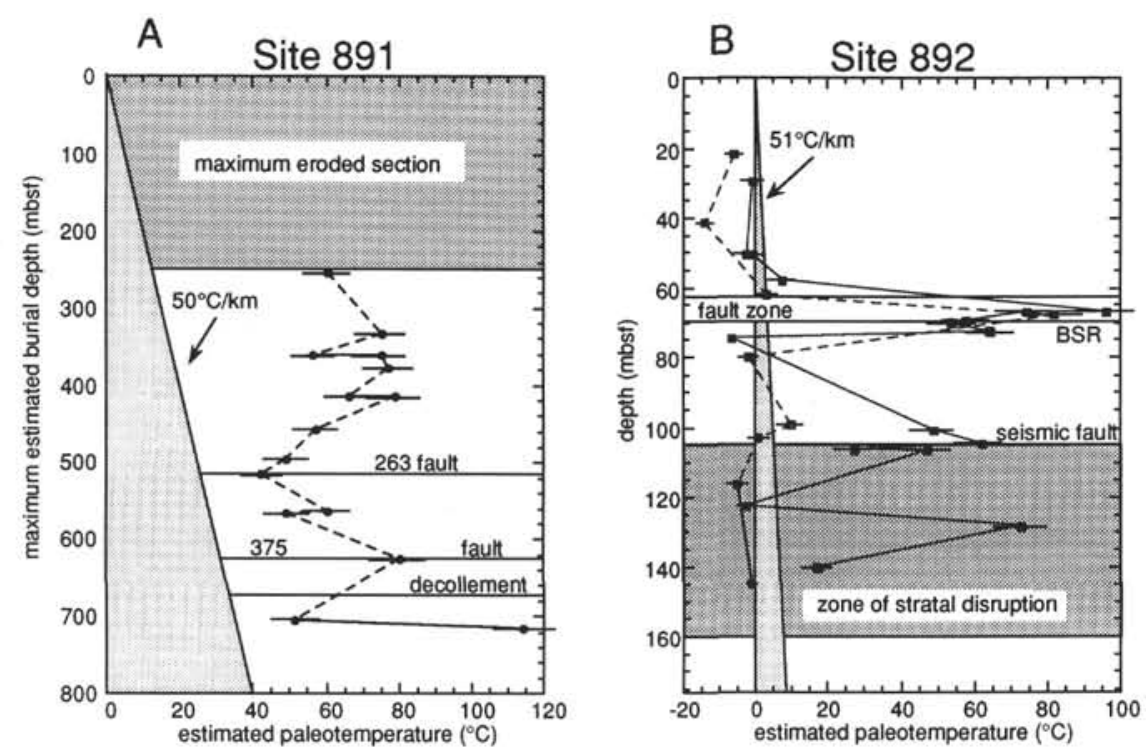

Figure 8. Plot of estimated temperatures versus estimated maximum possible burial depth for Site 891 and 892 diagenetic carbonate samples. A. Solid circles are temperatures estimated from oxygen isotopes, assuming a pore fluid composition of $-1.0 \%$ and using the calcite paleotemperature equation of (Craig, 1965). Horizontal bars show range of calculated temperatures using pore fluid compositions ranging from $-2 \%$ to $0 \%$. Stippled pattern represents maximum amount of sedimentary section removed by erosion during uplift of frontal ramp anticline (Westbrook, Carson, Musgrave, et al., 1994). Diagonally-lined pattern shows allowable temperature range for samples due to burial alone, assuming a continuous geothermal gradient of $50^{\circ} \mathrm{C} / \mathrm{km}$. Prominent fault horizons shown as horizontal lines. B. Open squares are temperatures estimated from oxygen isotopes for Hole 892A, solid squares for Hole 892D; assumptions and ranges are the same as for part A above. Diagonally-lined pattern shows allowable temperature range for samples due to burial alone, assuming a continuous geothermal gradient of $51^{\circ} \mathrm{C} /$ $\mathrm{km}$. Samples plotted to the left of this zone have the strongest ${ }^{18} \mathrm{O}$ enrichments, which may be due to dolomitic mineralogies and pore fluids enriched in ${ }^{18} \mathrm{O}$ by hydrate decomposition (above $80 \mathrm{mbsf}$, allowing for migration of base of hydrate zone over time). Stippled pattern represents shear zone defined in 892A from development of scaly fabric and broken formation (Westbrook, Carson, Musgrave, et al., 1994). Prominent seismic fault horizon at $105 \mathrm{mbsf}$ lies at top if the zone of stratal disruption; fault zone shown as white rectangle between 62.5 to $67.5 \mathrm{mbsf}$, BSR $(\approx 72 \mathrm{mbsf})$ located just below this fault zone.

arc, strontium released from glass alteration should have ${ }^{87} \mathrm{Sr} /{ }^{86} \mathrm{Sr}$ ratios of about 0.703 to 0.705 (Church and Tilton, 1973; Peterman et al., 1970). Volcanic glass alteration might be reflected in the modern pore fluid profiles by a decrease in $\mathrm{Mg}$ and a corresponding increase in Ca concentrations (Gieskes and Lawrence, 1981). At Site 891 there is no obvious correspondence between variations in $\mathrm{Ca}$ and $\mathrm{Mg}$ concentrations and variations in oxygen isotopes (Figs. 2 and 6), consistent with the interpretation that modern pore fluids cannot be used as proxies for pore fluid compositions at this site during carbonate precipitation. Furthermore, the radiogenic strontium isotopes of carbonates from Site 891 suggest that alteration of volcanic matter is not a likely source of ${ }^{18} \mathrm{O}$ depletion in the carbonates. Formation of gas hydrate is also an unlikely cause of the ${ }^{18} \mathrm{O}$ depletion in the carbonate precipitates, because the shift in pore fluid composition would be too small, and no evidence for hydrates is observed in the cores or in seismic reflection profiles from the area. Flow of meteoric fluids from the continent cannot be completely ruled out as a fluid source, but the tectonic position of the site makes it difficult to account for a suitable fluid conduit. Detrital carbonate is unlikely as a source of the oxygen and strontium isotope signatures, because carbonate rhombs (calcite and dolomite) of diagenetic origin are identified as the major type of carbonate in the sediments.

A decrease in fractionation of ${ }^{18} \mathrm{O}$ between a previous pore fluid and carbonate precipitates at elevated temperature is probably the most likely source of depletion of ${ }^{18} \mathrm{O}$ in the carbonates. If the pore fluids are considered to be an infinite reservoir of oxyger. lative to the carbonate cement, then the $\delta^{18} \mathrm{O}$ values of the cement will approach the lower $\delta^{18} \mathrm{O}$ values of the pore water. This is a reasonable assumption given the probable coarse nature of the sediments at Site 891. By assuming that the pore fluids have a $\delta^{18} \mathrm{O}$ value of $-1 \%$, the ambient temperature during carbonate precipitation for each sample can be calculated (Fig. 8). The estimated temperatures for carbonate precipitation at Site 891 range from $40^{\circ}$ to $115^{\circ} \mathrm{C}$. Such values can be due to high burial temperatures or advection of hot fluids. Sufficient temperature data were not obtained at this site to estimate its geothermal gradient, but the geothermal gradients measured at the other three sites at this margin range from $51^{\circ}$ to $68^{\circ} \mathrm{C} / \mathrm{km}$. The higher value was obtained at Site 888 , where the oceanic crust is 2 Ma younger than at Site 891 . Assuming a gradient of $50^{\circ} \mathrm{C} / \mathrm{km}$ at Site 891 and that the temperature estimate of $115^{\circ} \mathrm{C}$ is reasonable would require a depth of origin for the fluids of 1 to $2 \mathrm{~km}$. This depth would decrease somewhat if erosion of overburden is considered. Seismic reflection data from the region and physical property data from Site 891 suggest that up to $250 \mathrm{~m}$ of sediment has been eroded from the section (Westbrook, Carson, Musgrave, et al., 1994). If this is taken into account, the calculated temperature from oxygen isotopes can be compared with the estimated maximum depth of burial (Fig. 8). In this case there is still a residual difference between calculated temperatures of carbonate formation and the estimated maximum paleotemperature at the depth of carbonate formation of about $80^{\circ} \mathrm{C}$ at the bottom of the hole. A depth of fluid origin of greater than $1 \mathrm{~km}$ below the depth of carbonate formation is still required. Of course, assuming different values for the geothermal gradient and for pore fluid $\delta^{18} \mathrm{O}$ values at this site could eliminate some of the residual difference (Fig. 8); however, the oxygen data indicate that warm fluids have migrated upward along discrete horizons in the past, and carbonate cements formed during these periods of migration. Unfortunately the presence of warm fluids today could not be verified because of the failure of all of the downhole temperature measurements at Site 891 (Foucher et al., this volume).

Strontium isotopes from the carbonates can constrain further the source of fluids for the carbonate precipitates. As already stated, the ${ }^{87} \mathrm{Sr} /{ }^{86} \mathrm{Sr}$ ratios are more radiogenic than modern seawater and are too high to indicate strontium derived from the alteration of intermediate to mafic volcanic matter. Breakdown of radiogenic strontium-bearing phases in the sedimentary section could provide the necessary source of high ${ }^{87} \mathrm{Sr} /{ }^{86} \mathrm{Sr}$ ratios (Sample et al., 1993). Likely phases in the Cascadia basin would be clay minerals derived from reworking or alteration of cratonal North American crust. These phases presumably would be transported to the Cascadia sea floor as turbidites with a source in the Columbia River, because most of the lithologies found near the coastline are too mafic and juvenile. 
The isotope characteristics of diagenetic carbonates from Site 892 differ in a number of important ways from Site 891, and suggest that carbonates record both shallow and deep fluid sources at Site 892 . The stable isotope profiles are more complex at Site 892, perhaps reflecting a longer history of fluid flow and deformation. At Site 892, carbon isotopes have a large range in values, from $-31 \%$ o to $+12 \%$. Oxygen isotopes show both depletions and enrichments of ${ }^{18} \mathrm{O}$. With one exception, the ${ }^{87} \mathrm{Sr}{ }^{86} \mathrm{Sr}$ ratios are all substantially lower than modern seawater.

Light carbon isotopes in continental-margin settings typically reflect a carbon source of oxidized methane (Claypool and Kaplan, 1974). It is difficult to distinguish whether the carbon source is thermogenic methane (typically $-50 \%$ to $-25 \%$ ) ) or a mixture of biogenic methane (typically $-90 \%$ to $-75 \%$ ) and a heavier carbon source. Thermogenic hydrocarbons were recognized at depths as small as 68 mbsf at Site 892. Most of the lightest carbonates were found above this depth, but thermogenic methane could have been present higher in the section in the past. The existence of abundant carbonates enriched in ${ }^{13} \mathrm{C}$ is similar to results obtained from the Peru margin (Thornburg and Suess, 1990). The only source for such strong enrichments is carbon dioxide evolved from fermentation reactions in the sediment column, which typically has $\delta^{13} \mathrm{C}$ values of $+15 \%$. $\delta^{13} \mathrm{C}$ values of carbon dioxide from many of the gases in Site 892 are in the range expected for this carbon source (Whiticar et al., this volume). This confirms our assumption that the carbon reservoir for ${ }^{13} \mathrm{C}$-enriched is in the zone of fermentation, and that carbon originated from shallow sources at Site 892, because the depth of sulfate exhaustion is less than 10 mbsf at Site 892 (Westbrook, Carson, Musgrave, et al., 1994). With only one exception, cements strongly enriched in ${ }^{13} \mathrm{C}$ are also enriched in ${ }^{18} \mathrm{O}$ (Fig. 4). This relationship is consistent with a shallow fluid source for these cements, because high $\delta^{18} \mathrm{O}$ values are more typical of dolomitic carbonates precipitated at or near the sea floor at low bottom-water temperatures (Sample et al., 1993). Precipitation in the zone of gas hydrate formation would also result in high $\delta^{18} \mathrm{O}$ values, because the decomposition of hydrates would enrich the pore fluids in ${ }^{18} \mathrm{O}$. We suggest that high $\delta^{18} \mathrm{O}$ values at Site 892 are diagnostic of carbonates whose fluid reservoir was dominated by shallow sources, and the cement probably formed at or near the sea floor. If this designation is correct, then the carbonates with high $\delta^{18} \mathrm{O}$ values and low $\delta^{13} \mathrm{C}$ values also had a fluid reservoir dominated by local, shallow fluids. The apparent thermogenic carbon isotope values can be explained by a mixed carbon source of oxidized biogenic methane and biogenic carbon dioxide, both evolved in the upper few tens of meters in the zone of fermentation.

A significant group of diagenetic carbonates at Site 892 has strong ${ }^{18} \mathrm{O}$ depletions and mild ${ }^{13} \mathrm{C}$ depletions (Fig. 4), similar to the carbonates from Site 891 . Because Site 892 is closer to the shelf and shoreline than Site 891, meteoric fluids as a source of ${ }^{18} \mathrm{O}$ depletions merits more consideration at Site 892. Sample 146-892D-10X-5, 98-100 $\mathrm{cm}$, contains fibrous and sparry calcite veins that have a $\delta^{18} \mathrm{O}$ value of $-7.1 \%$. Similar textures and oxygen isotope values are observed in carbonates from Peru (ODP Leg 112), where there is supporting evidence that the host sediments were once exposed to meteoric weathering. Similar corroborating evidence for meteoric weathering does not exist at Site 892, however, where benthic foraminifers and the lithostratigraphy indicate deposition occurred in a lower bathyal environment on the abyssal plain (Westbrook, Carson, Musgrave, et al., 1994). Sediments at Site 892 have probably experienced a relatively continuous uplift history, rather than the severe subsidence that has been inferred for sediments at Peru. Thus, although meteoric fluids cannot be eliminated as a source at Site 892 , we prefer the interpretation that precipitation from warm fluids caused ${ }^{18} \mathrm{O}$ depletions in Site 892 carbonates, similar to Site 891 .
A plot of variations with depth in estimated paleotemperatures during cementation, based on oxygen isotope data, indicates that the largest apparent temperature anomalies occur at zones recognized to be major faults or fluid conduits (Fig. 8). In particular, the fault zone between 62 and $69 \mathrm{mbsf}$ and the seismically-imaged fault at $105 \mathrm{mbsf}$ show the largest temperature anomalies. The zone of stratal disruption shows a more complicated signal; generally Hole 892A does not show a pronounced calculated anomaly, while two samples from Hole 892D show calculated anomalies of $10^{\circ}$ and $67^{\circ} \mathrm{C}$. The zone of the highest paleotemperature anomaly at $62-68 \mathrm{mbsf}\left(\approx 100^{\circ} \mathrm{C}\right)$ coincides with one of the anomalous temperatures recorded at $67.5 \mathrm{mbsf}$ (Westbrook, Carson, Musgrave, et al., 1994), but none of the current downhole temperatures approaches the required paleotemperature. This suggests that if warm pulses of fluid migrate up fluid conduits, the pulses are episodic, and the current thermal characteristics of Site 892 do not reflect the conditions during precipitation of the ${ }^{18} \mathrm{O}$-depleted carbonates.

The ${ }^{87} \mathrm{Sr} /{ }^{86} \mathrm{Sr}$ ratios at Site 892 are mostly less radiogenic than modern seawater. The ${ }^{18} \mathrm{O}$-enriched carbonates tend to have ${ }^{87} \mathrm{Sr} /{ }^{86} \mathrm{Sr}$ ratios closest to seawater (Fig. 7), which suggests that the strontium reservoir of these samples was derived from relatively shallow sources in the section. However, most of the carbonates analyzed have ratios too nonradiogenic to be dominated by seawater values of the last fifty million years (DePaolo and Ingram, 1985). Therefore the source of strontium for these samples must be from the sediment matrix. The most ${ }^{18} \mathrm{O}$-depleted samples have the lowest ${ }^{87} \mathrm{Sr} /{ }^{86} \mathrm{Sr}$ ratios, suggesting a correlation of oxygen and strontium isotopes at Site 892. This relationship suggests that sediments beneath Site 892 have a higher component of volcanic matter than sediments beneath Site 891. One diagenetic carbonate from Site 892 was depleted in ${ }^{18} \mathrm{O}$, but had a very radiogenic ${ }^{87} \mathrm{Sr} /{ }^{86} \mathrm{Sr}$ ratio (Sample $146-892 \mathrm{D}-9 \mathrm{X}-3,87-89 \mathrm{~cm}$ ). This sample was located in the zone of the highest paleotemperature anomaly at $72 \mathrm{mbsf}$ (Fig. 8). This indicates that at significant depth beneath Site 892 there may be a source of radiogenic strontium similar to the source at Site 891.

\section{CONCLUSIONS}

The differences in carbonate geochemistry between Sites 891 and 892 reflect different hydrogeological characteristics between the present and the past. Some of the variations between sites may reflect the differences in sample recovery, but not all variations can be explained in this way. The amount of diagenetic carbonate is higher at Site 892 , suggesting that with continued fluid flow, sediments are becoming more lithified due to tectonically-related dewatering and cementation. The depth profiles of stable isotopes evolve from less to more complex from Site 891 to Site 892. In subduction systems, it may be inevitable that isotope characteristics become more complex with increasing distance from the trench, because of mixing of sources important during carbonate cementation and because of physical tectonic mixing of cements by continuing deformation.

Oxygen isotopes suggest significantly higher paleotemperatures at some horizons in each site. At Site 891, a large anomaly occurs along a major fault at $375 \mathrm{mbsf}$, and the largest anomaly occurs beneath the frontal thrust at $468 \mathrm{mbsf}$. The largest anomalies at Site 892 occur at 62 to $70 \mathrm{mbsf}$, and in Hole 892D at 100 to $105 \mathrm{mbsf}$. The horizons at both sites are along or near major fault zones, suggesting that significant flow of warm fluids from depth has occurred along the faults. However, the 468-mbsf anomaly at Site 891 is at a horizon with significant sand in the core, and the anomaly between 62 and 70 mbsf is associated with the only major gravel layer recovered on the leg. These relationships between apparent flow horizons and perme- 
able lithologies suggests that stratigraphic flow also may be important at both sites.

An important advantage of studying the chemistry of cements along with pore fluids is that the carbonates preserve a longer history of the hydrogeology of the accretionary wedge. Paleotemperature estimates of cement formation from Site 891 suggest that most of section has experienced upward or lateral advection of warm pore fluids. Many of these horizons were not recognized as fluid conduits based on other information recovered from the section. At Site 892, there is a greater correspondence between recognized fault zones or fluid conduits and zones of anomalous paleotemperatures, suggesting that at that site, either the carbonates formed recently, or the recognized fault zones have experienced long histories of fluid flow.

\section{ACKNOWLEDGMENTS}

This paper benefited from thoughtful reviews by Erwin Suess, Todd Thornburg, and Marta Torres, as well as informal discussions with the scientists of Leg 146. The assistance of Dennis Graham, Anne Pimmel, and Brad Julson was invaluable in keeping shipboard chemical measurements proceeding smoothly. Elihu Goldish, Rulah Kafity, Ron Thompson, Pete Tauscher, and Ross White assisted with $\mathrm{XRD}$ analysis at CSULB. Isotope analyses were handled very capably by Pete Holden and Dave Winter at UCLA. Research was supported by post-cruise grant from USSAC.

\section{REFERENCES}

Church, S.E., and Tilton, G.R., 1973. Lead and strontium isotopic studies in the Cascade Mountains: bearing on andesite genesis. Geol. Soc. Am. Bull., 84:431-454.

Claypool, G.E., and Kaplan, I.R., 1974. The origin and distribution of methane in marine sediments. In Kaplan, I.R. (Ed.), Natural Gases in Marine Sediments: New York (Plenum), 99-139.

Craig, H., 1965. The measurement of oxygen isotope paleotemperatures. In Tongiorgi, E., (Ed.), Stable Isotopes in Oceanographic Studies and Paleotemperatures, Spoleto, 1965: Pisa (Consiglio Nazionale delle Ricerche, Laboratorio di Geologia Nucleare), 1-24.

Demets, C., Gordon, R.G., Argus, D.F., and Stein, S., 1990. Current plate motions. Geophys. J. Int., 101:425-478.

DePaolo, D.J., and Ingram, B.L., 1985. High-resolution stratigraphy with strontium isotopes. Science, 227:938-941.

Gieskes, J.M., and Lawrence, J.R., 1981. Alteration of volcanic matter in deep-sea sediments: evidence from the chemical composition of interstitial waters from deep-sea drilling cores. Geochim. Cosmochim. Acta, $45: 1687-1703$

Kastner, M., Elderfield, H., Jenkins, W.J., Gieskes, J.M., and Gamo, T., 1993. Geochemical and isotopic evidence for fluid flow in the western Nankai subduction zone, Japan. In Hill, I.A., Taira, A., Firth, J.V., et al., Proc. ODP, Sci. Results, 131: College Station, TX (Ocean Drilling Program), 397-413.
Kulm, L.D., and Suess, E., 1990. Relationship between carbonate deposits and fluid venting: Oregon accretionary prism. J. Geophys. Res., 95:8899-8915.

Kulm, L.D., Suess, E., Moore, J.C., Carson, B., Lewis, B.T., Ritger, S.D., Kadko, D.C., Thornburg, T.M., Embley, R.W., Rugh, W.D., Massoth, G.J., Langseth, M.G., Cochrane, G.R., and Scamman, R.L., 1986. Oregon subduction zone: venting, fauna, and carbonates. Science, 231:561566.

Kulm, L.D., von Huene, R., et al., 1973. Init. Repts. DSDP, 18: Washington (U.S. Govt. Printing Office).

Linke, P., Suess, E., Torres, M., Martens, V., Rugh, W.D., Ziebis, W., and Kulm, L.D., 1994. In situ measurement of fluid flow from cold seeps at active continental margins. Deep-Sea Res., 41:721-739.

MacKay, M.E., Moore, G.F., Cochrane, G.R., Moore, J.C., and Kulm, L.D., 1992. Landward vergence and oblique structural trends in the Oregon Margin accretionary prism: implications and effect on fluid flow. Earth Planet. Sci. Lett., 109:477-491.

McCrea, J.M., 1950. On the isotope chemistry of carbonates and a paleotemperature scale. J. Chem. Phys., 18:849-857.

Moore, J.C., Orange, D., and Kulm, L.D., 1990. Interrelationship of fluid venting and structural evolution: Alvin observations from the frontal accretionary prism. J. Geophys. Res., 95:8795-8808.

Peterman, Z.E., Carmichael, I.S.E., and Smith, A.L., $1970 .{ }^{87} \mathrm{Sr} /{ }^{86} \mathrm{Sr}$ ratios of Quaternary lavas of the Cascade range, northern California. Geol. Soc. Am. Bull., 81:311-318.

Ritger, S., Carson, B., and Suess, E., 1987. Methane-derived authigenic carbonates formed by subduction-induced pore water expulsion along the Oregon/Washington margin. Geol. Soc. Am. Bull., 98:147-156.

Sample, J.C., and Reid, M.R., in press. Fluid migration and expulsion along strike-slip and thrust faults in the Oregon convergent margin: evidence from the geochemistry of syntectonic carbonate cements and veins. Earth Planet. Sci. Lett.

Sample, J.C., Reid, M.R., Tobin, H.J., and Moore, J.C., 1993. Carbonate cements indicate channeled fluid flow along a zone of vertical faults at the deformation front of the Cascadia accretionary wedge (Northwest U.S. coast). Geology, 21:507-510.

Thornburg, T.M., and Suess, E., 1990. Carbonate cementation of granular and fracture porosity: implications for the Cenozoic hydrologic development of the Peru continental margin. In Suess, E., von Huene, R., et al., Proc. ODP, Sci. Results, 112: College Station, TX (Ocean Drilling Program), 95-109.

Veizer, J., 1983. Trace elements and isotopes in sedimentary carbonates. In Reeder, R.J. (Ed.), Carbonates: Mineralogy and Chemistry: Washington, DC (Mineral. Soc. Am.), 265-300.

Vrolijk, P., and Sheppard, S.M.F., 1991. Syntectonic carbonate veins from the Barbados accretionary prism (ODP Leg 110): record of paleohydrology. Sedimentology, 38:671-690.

Westbrook, G.K., Carson, B., Musgrave, R.J., et al., 1994. Proc. ODP, Init. Repts., 146 (Pt. 1): College Station, TX (Ocean Drilling Program).

Date of initial receipt: 2 September 1994

Date of acceptance: 17 March 1995

Ms 146SR-235 


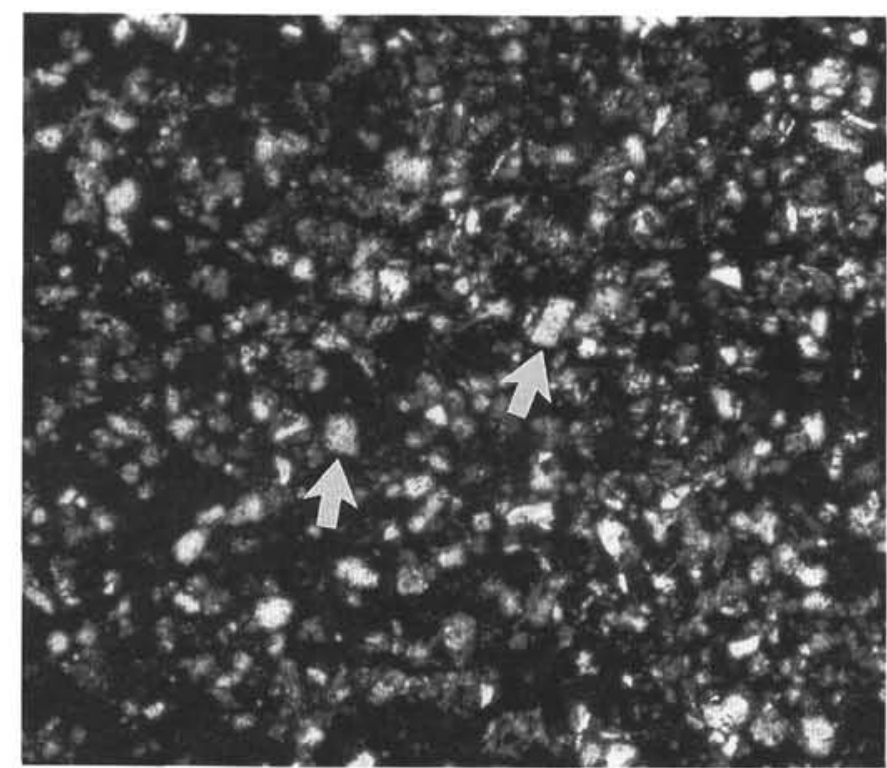

1

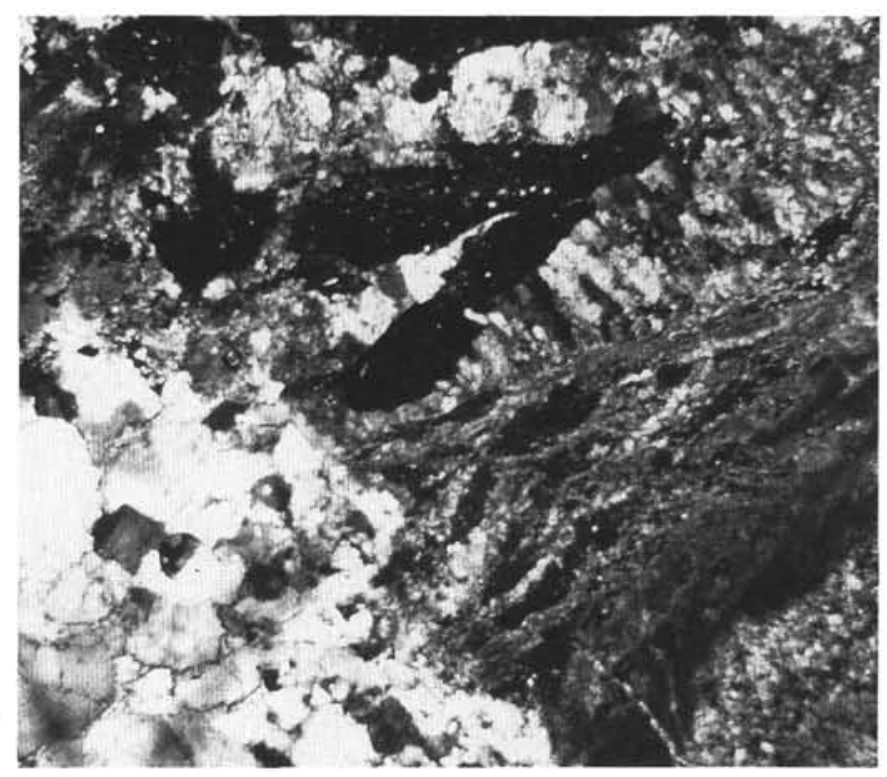

2

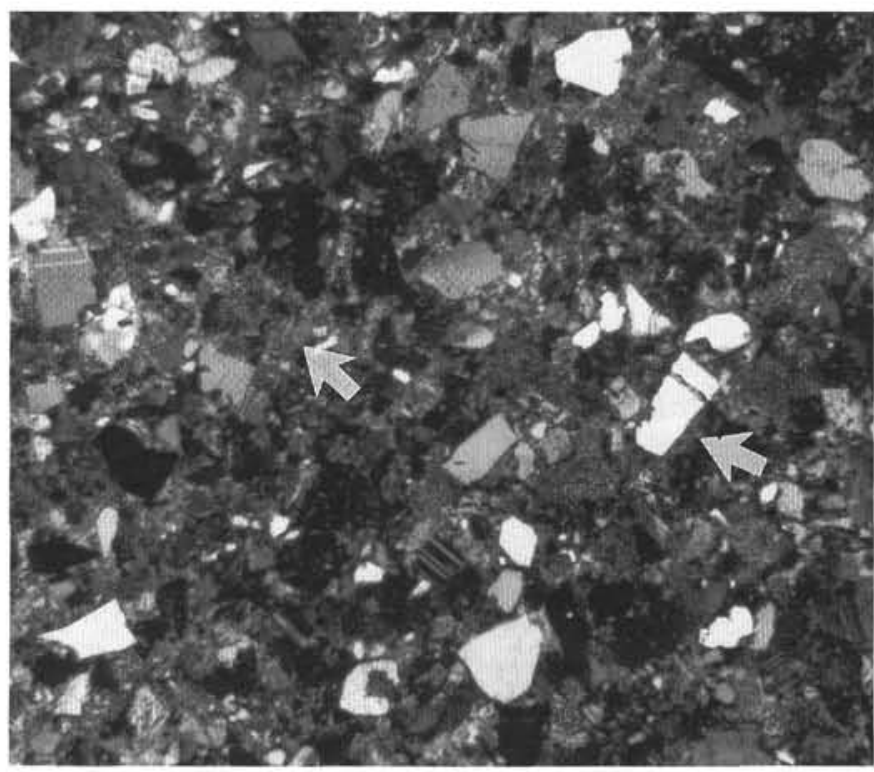

3

Plate 1. Photomicrographs of occurrence of inorganic carbonate precipitates at Sites 891 and 892. 1. Sample 146-891B-14X-1, 85-89 cm, showing dolomite rhombs (arrows). Thin section of grain mount, crossed polarizers, field of view $=1.3 \mathrm{~mm}$. 2. Sample 146-892D-10X-5, 98-100 cm showing fibrous and sparry textures in calcite veins. Crossed polarizers, field of view $=4.2 \mathrm{~mm}$. 3. Sample 146-892A-9X-1, 20-22 cm showing pore-filling cement (arrows). Crossed polarizers, field of view $=4.2 \mathrm{~mm}$. 